\title{
The Influence of Learning Method and Learning Style of the Ability for English Students of Akademi Pariwisata Satu Nusa Bandar Lampung
}

\author{
Rara Agustina \\ Akademi Pariwisata Satu Nusa \\ raraagustina13081990@gmail.com
}

\begin{abstract}
The purpose of this research is to know and analyze the effects of learning method and learning style to influence the ability for English students of Akademi Pariwisata Satu Nusa Bandar Lampung. This research consisted of forty two respondent on Akademi Pariwisata Satu Nusa Bandar Lampung. In the methode do applying for collecting data by documentation study, observation and interview, and then the angket. For processing data using the multiple regression analysis to know relation indefendent variable (X1) method of learning and (X2) learning style to influence defendant variable $(\mathrm{Y})$ ability of English students. Furthermore in its data analysis using SPSS Statistics 24 program. In addition, the results of these research appeared that by significant 0,05 for two side test $2,5 \%$ and $n=42$ to obtain $t$ statistics's table 2,023. But t from testing 2,731 for method of learning, and 3,119 for learning style therefore method of learning and learning style has positive significant influences for the ability of English students of Akademi Pariwisata Satu Nusa Bandar Lampung. This result could be explained that testing of $F$ and testing of $t$ statistics. $F$ statistics's table 3,238 but $F$ testing 9,141 by statistics's table. Therefore, it can be conclude that there is any positive significant influences on English students' ability of Akademi Pariwisata Satu Nusa Bandar Lampung.
\end{abstract}

Keywords: Learning Method, Learning Style, and Ability of English Students

\section{INTRODUCTION}

Having the ability in English serves as skill is needed in the market share of current. The English provides much of the benefits the current. The reason why the English required for now are learning English hoped to enable, in search of work ease in established, social interaction increase, career ease in knowledge or add reading materials outside the national perspectives so that it can open, on science and technology and there are many other benefits.

English is an important international language that would connect the community with the world in a variety of spec including educational aspect. Communication can be achieved if somebody got four language skills: listening, talking, read, and write. This shall also apply to the process of language acquisition england called listening and reading as receptive skill while reading and speaking as productive skill. Often a man proclaims that only by controlling speaking, him it can be said proficient in. This is not entirely true. Language wrote also important to controlled. For example, when we open the internet and wanted to follow email, of course needed ability to read a careful and writing ability with the structure of a language right so that it can be answering appropriate. College is a institution that very responsible for progress and intelligence the to be able to compete with other nations.

Learning English, relevant competence college has an important role to students in order to compete in the workplace. Not just focus on mastery of English for the benefit of academic or English for academic purpose but learning English oriented to interest or demands of the world of work in the field of science each. This indicates that basic English language teaching in college not supposed to oriented best interest in academic but also aimed to create graduates with high capability in in order to have competence English required by the field of employment certain (English for occupational purpose) within a group the field of different science.

Akademi Pariwisata Satu Nusa is the only one tourism academy in the province of lampung. As education providers tourism, this college have high awareness also in response to the importance of English for now this. Thus, this college to pay special attention of the ability of English students. 
42 | Channing: English Language Education and Literature Vol. 5 No. 2 Oktober 2020 Halaman: 41-51

Based on pre survey done by researchers is fact related students ability speak English on Akademi Pariwisata Satu Nusa. Here the score toefl data of test (English the us of a foreign students languange) Akademi Pariwisata Satu Nusa 2020.

Table 1. Pre survey data test students of AKPARSAN

\begin{tabular}{|l|l|l|}
\hline \multicolumn{1}{|c|}{ Criteria } & Amount & \multicolumn{1}{c|}{ Percentage } \\
\hline Pass & 18 & $42,86 \%$ \\
\hline Not Pass & 24 & $57,14 \%$ \\
\hline Total Students & 42 & $100 \%$ \\
\hline \multicolumn{2}{|c|}{ (Pre Survey Results, 2020) }
\end{tabular}

Based on table above shows that more than 50 percent of the $55 \%$ students in January 2020 having value TOEFL under criteria, namely 425 .More than thirty percent of the students having results a score toefl under criteria indicates that the limited English students of Akademi Pariwisata Satu Nusa.

Related to the data, researchers are interested to have an assessment on factors influencing the capacity of English-speaking students on Akademi Pariwisata Satu Nusa with the hope of helping to improve the ability of English-speaking students both to meet academic standards and meet the needs of the world of work in the field of tourism. There are several factors that can affect the ability English students including lecturer's method of learning and students learning style. According to brown (2001: 169-171) teaching techniques all exercises, activity or instrument used in the classroom language to create the purpose of learning. We can conclude that teaching techniques is all activities that can be used by lecturers in the process teaching taken and adapted from a method of teaching and his approach. In other words, when a teacher wanted to use a certain techniques, he has to match such techniques with the methods and also the approach that will be used in the process of learning.

The definition of Reid who was quoted by Suparman (2010: 100) revealed that learning style was referring to the habit of a student whose nature is natural in relation to absorb and process to get. Ability to new information in general any 3 kind of style learn visual: (see), auditory (heard) and a kinesthetic (move).

Based on the background problems have made the formulation matter as:

1. How the influence of learning methods to English students of the ability on Akademi Pariwisata Satu Nusa in Bandar Lampung?

2. How the influence English students style to English students of the ability on Akademi Pariwisata Satu Nusa in Bandar Lampung?

3. How the learning methods and English students style is together to English students of the ability on Akademi Pariwisata Satu Nusa in Bandar Lampung?

Think of the background and problems that had been presented, then this is the main research:

1. To test the learning methods in the ability of students learning English on Akademi Pariwisata Satu Nusa in Bandar Lampung.

2. To test influence style in the ability of students learning English on Akademi Pariwisata Satu Nusa in Bandar Lampung.

3. To test influence learning methods and style is together in the ability of students learning English on Akademi Pariwisata Satu Nusa in Bandar Lampung.

\section{The Ability in Speaking}

The ability in speaking according to Depdiknas (2005:3) is "the extent to which an individual of symbols and the signification of language". The definition of ability according to KBBI (2012::707) derived from a capable of authority or meaning can do something, be a suffix and be aptitude that may be as much as; and all skills; and strength. Thus in language ability can be defined or, as much as and. skills a person can be said to when she/he could do something had to do.

Thoha (1998: 154) explained that the ability is one of the elements in ripeness relating to 
knowledge and skills that can be obtained through education, training and an experience. According to opinion Thoha up explained that the ability can be obtained through various kinds of ways, among other things, education training and experience.

It can be concluded that the ability is as much as, maturity, and skill of a person in an skills and knowledge that can be beneficial for both for himself and others, this capability can be obtained by various efforts, among other: education, training and experience.

Soenardi (2011: 8) divided into four types ability, among other: ability to review, ability to read, the ability to speak, and writing ability. The opinion of the Soenardi have been further strengthened with some expert opinions and the community figures stated that, to very speaking someone so need to pay attention to the ability of scrutinizing; the capability of reading; the ability to speak and writing ability. Nurjamal is among the figures have an opinion aligned with Soenardi. Nurjamal (2011:2) explained that: language skills consists of four aspects namely listening skills, talk skills (speaking skills), reading skill, and writing skills.

\section{The Ability to Review}

1. Understanding Review

According to Soenardi (2011: 8) all his is the ability to understand something expressed others orally in the form of words off, discourse short to pass sentence, or discourse long spoken, as exposure to speech, lectures and others. Moreover, Tarigan (2008:31) is a listening process symbol of oral attentively, understanding, appreciation, and interpretation to obtain information, catch the contents or message, and understand the meaning of a communication that outlined the speech or language spoken by the speaker. Meanwhile, Abbas (2006: 63) is: listening is a process for the organized what would be heard and put a voice mail voice be heard and arrested become the meaning of being acceptable.

Based on some experts above, can conclude that the listening is a process the arrest of spoken language that deliberate and intentional means of the then analyzed in order to understand the contents of the material.

\section{The Purpose of Review}

The Review in learning and in daily life of course have a purpose to be achieved. .Another argument expressed Tarigan (2008: 62) stated that, the purpose are as follows:
a. The review to learn,
b. The review to enjoy,
c. The review to evaluate,
d. The review to apreciate,
e. The review to comunication the idea,
f. The review to distinguish the noise,
g. The review to solve the problem,
h. The review to convince.

\section{The Factors Effect of Ability to Review}

A variety of studies which have been taken by experts it can be seen that learning the ability of scrutinizing has had its very particular difficulties if a comparison is made by learning to other speaking skills.

According to the Hermawan (2012: 49-54), factors affect could be divided into two the: internal and external factors:

a. Internal Factors.

The internal factors can influence on the ride is a problem hearing and the physical condition of. When a person hearing or suffer problems damage the auditory could impede the waves in a given 
volume, then the process would be disturbed. Listening nor when the physical condition of unhealthy when cannot focus on talks others kindly. Another factor were the limited to simultaneously all we heard. Many a listener can only half of a verbal message given others each day. Therefore if not always well to the attention. A further factor is think was too fast, difficult doing activity in its careful. When spare time to take is mind while others talk, usually they think things unrelated to the speaker, as self-interest, was, disproved plan etc. The process of review is also influenced by motivation and a feeling of listeners that time (personal) interest. A listener will scrutinizing the more effective, and consciously select what is heard especially in times of need or want the information

\section{b. Eksternal Factors}

The external covering environmental factors, the material, the speaker, speaking style and technique. Talks can understand the influence on the matter. Listeners will be more interested in new matter compared with material that has known or experienced. The speaker also reach the attention of listeners .For example, speaker who experience and looking calm would be more persuasive than the speaker who nervous. On top of that style, appearance, and technique will be the presentation of material is one factor with understand as visualize and influence on the technology used.

Machackova (2009: 15) more detailed explained that there was some sort of difficulty in his learner in relation to the ability of a foreign language, in this especially English, the:

1) Unable to understand pronunciation

2) Cannot control rapidity of speech speakers of

3) Back not can repeat what is heard

4) Limited vocabulary

5) Learner difficulty / failure in concentrate

6) Distinction knowledge shared who caused the difference interpretation

7) Inability in understanding signs words

8) Limited access in learning materials otentik

9) Absence visual element can help understanding.

\section{The Ability to Read}

1. Sense of Read

Soenardi (2011: 8) states that can read pointed to an ability to understand the purpose and the minds of people who expressed in writing in the form of, exemplified the following: a short note, a letter, newspaper articles, short stories, novels and lain-lain. Reading is a skill that is essential for controlled by individuals. Tarigan (2008:7), "reading is the one conducted and used by readers to get message, was delivered by the writer through the written".

\section{The Factors Affect Ability to Read}

Ability to read is complex event, and many ways and many factors influence it. Nurbiana (2006:3-18) suggested the motivation, family environment, reading materials and teachers are of factors affect. The opinion also raised by Tampubolon (1990:90-91) that can read factors influencing the divided into two parts, the endogenous exogenous factors and exogenous factors. The endogenous factors is a within oneself. And exogenous factors is the factor that is from outside person.

\section{The Ability to Speak}

1. Sense of Speak

Soenardi (2011: 8) stated that the ability to speak is: ability to express thoughts and heart someone through the sounds of a language and words strung together in the structure of the language more complete as, phrases, sentence and oral discourse longer, as the story speech and others.

The ability to speak is one of the quality of language acquisition, including English. Iskandarwassid (2011: 13) said that this capability is also justified by "trust a person to talk to, honest, right and 
responsible by removing psychiatric problems like embarrassment, inferiority, tension, difficult language and other".

2. The Factors Affect Ability to Speak

Burns and Joyce (1997: 134) wrote that there are three factors that makes students are reluctant to participate in tasks in class:

a. First, because the students thought that learning a language by listening to teachers, enough understand reading writing from textbooks and do; exercises.

b. Second, linguistic difficulty is the difficulties faced understand the difference between a mother tongue and a language, learned understand nothing with pronunciation, native speakers understand the difference grammar and difficulty of the mother and learned English language.

c. The third psychological factors and the other factors, for example, culture factors, experience, less motivation, anxiety and shame speak in the classroom.

\section{The Ability to Write}

\section{Sense of Write}

According to Tarigan (2009:21) is sighing and expressing the hearts in a form of. Skill writing not came straight by itself, but must go through much practice and practices regularly. Writing also and sent down or delineating symbols these graphs it if they understand language and a charts. Drawing or painting might to the meaning of, but did not illustrate unitary language. Composing constituting a representation part of unitary expression language.

Besides, Harmer (2007:325) said that there are various stage in the process of writing that is drafting, review, rewrite, the last one is conducted in recursive writing at the editing may be that it is necessary to return to the prewrite and think back. Pieces of writing can be edited as. Previous agenda. The writing including (1), check the use of language (2) check punctuation and, layout (3), check your spelling (4) check writing you to a needless repetition of, (5) specify information for every, paragraphs (6), write various ideas (7) select best ideas to put, (8) wrote a clean copy of a corrected, from version (9) write. Coarse version

\section{The Factors Affect Ability to Write}

According to Marwoto (2000: 16), the are several factors can Affect Ability to Write, are (1) rich in idea, (2) have a science extensive knowledge, (3) experiences vibrant deep, (4) having intuition sharp, (5) having soul wise, and (6) rich in language.

\section{The Learning Methods}

\section{Sense of Learning Methods}

Learning activities, in its implementation know many term to describe how to teach being taken by educator, so numerous species of a method of learning aimed at to improve the quality of learning for the better .The term strategy, method, approach, model and engineering and tactics learning so familiar in the world learning us. The following is a commentary about the terms:

1. Strategy is a learning activities to do teachers / lecturers and students that the purpose of learning by effectively or a device of learning producer used in together to cause. students learning outcomes. So required a method to realize the. set.

2. Method is the sight of made used to implement the implementation activities in order to achieve objectives specified.

3. Approach is turning point or viewpoints we to see all the problem in the learning.

4. Model is a plan or pattern used teachers / lecturers in organize, subject matter and the students guide for teachers how to teach in class.

5. Technique is how exercised by someone to implement a method of. So is skill and art to 
implement systematic steps in performing an for scholarly activities broader.

6. Tactics is in implementing method or somebody style tactics are learning certain individual (Madjid, 2012: 125).

The use of terms, mentioned above often felt the same but essentially different in the implementation and application. Pointing to a broader strategy to achieve something, planning required for its implementation methods using approach as benchmark and model as the principle of using tactics to apply the methods and tactics indicated in the teacher teaching style

\section{Method Selection of Learning}

According to Djamarah (2010: 222) the people teaching think that methodology teaching as the science help that cannot stand alone, but serves help other sectors in the process of learning. Therefore, the science help this is a flexible, its use based on taking into account as follows:

1. Always oriented on the objective

2. Not only attached to one alternative

3. Often used as a combination of various a method of

4. Often used shift from one a method by other methods

\section{The Learning Style}

\section{Sense of Learning Style}

Learning style is a method that belongs to individuals to get information, which in principle the style of learning an integral part of active cycle of learning. Learning style is more we like to conduct thinking, process and understand an information (Ghufron et.all, 2013: 10). According to Nasution (2009: 94) called learning style is a manner consistent carried out by a student in catching a stimulus or information, how to remember, think and solve problems. Not everyone has the same, learning style even if they were sitting in the same class.

\section{Types of Learning Style}

According to De Porter et. all. (2010: 110) in quantum learning stated that style is kind of learning, $3^{\text {rd }}$ are the visual, auditoria and a kinesthetic.

1. The Visual Learning Style

Style of this learning is learned by means of see something. According to de porter, namely the characteristics of the learning style visual style, that is:

a. Neat and orderly

b. Talk rapidly

c. Planning and regulator long-term good

d. Careful study of detail.

e. Appearance, seek in terms of clothes and presentation

f. Good speller and can see words actually in their minds

g. Considering what he saw i., than is heard

h. Remember with the visual

i. Usually undisturbed by ruckus

j. Have a problem to remember verbal instruktion unless written, and often for help people to repeat it

k. The quick readers and determine

I. More like to read than recited

m. Need sight and the thorough and be alert before mentally feel gotta be about a problem or project.

n. Scribble with no definition for speaking on the phone and in meeting.

o. Forget verbal message to others

p. Often said the question by curt answer yes or no. 
q. Preferred to demonstration than address

r. Prefer art rather than music

s. Often know what to say, but not choosing. words

t. Sometimes loss of concentration when they want to see.

2. The Auditorial Learning Style

The kind of learning style it is learning by means of heard. According to De Porter, et.all., (2010: 117) characteristic of people with learning style auditorial is:

a. Speak themselves they are

b. Easily disturbed by tumult.

c. Move the lips them and utter when he read the book.

d. Love reading loudly and listen

e. Can repeat back and a tone, birama, and color sound.

f. They had difficulty to write, but good at their

g. Speak in a composition patterned

h. Usually eloquent speaker

i. Prefer music of on art.

j. Learn by listen and remember what discussed than seen

k. Talk, like discuss, and explaining things at length

I. Have a problem with with, involving visualize as cutting away parts to accord each other.

m. Smarter spell with violent than write

n. Prefer bantering spoken than read comic.

3. The Kinesthetic Learning Style

The kind of learning style it is learning by manner of move, work and touch. According to De Porter, et.all (2010: 119) characteristic the people with a kinesthetic learning style: among other things:

a. Talk to slowly

b. Response to physical attention

c. To touch people to get their attention

d. Standing near when talk to people

e. Always oriented to physical and move far

f. Have early development the muscles a great

g. Learn through the manipulation of and practices

h. Memorization by manner of walking and see

i. Use the fingers as pointer while reading

j. Many use these cues the body

k. Not can sit to a long time

I. Could not recall geography, unless they it has been in the place

$\mathrm{m}$. Using words that containing action

n. Love books oriented to plot-they reflect action with movement of the body while reading

o. The possibility of his writings ugly.

p. Want to do all things

q. Love game then.

Based on a variety of the discussion above about the methods of learning, and learning style against England and language skills may be prepared, research paradigm as shown in figure .1. Under this: 


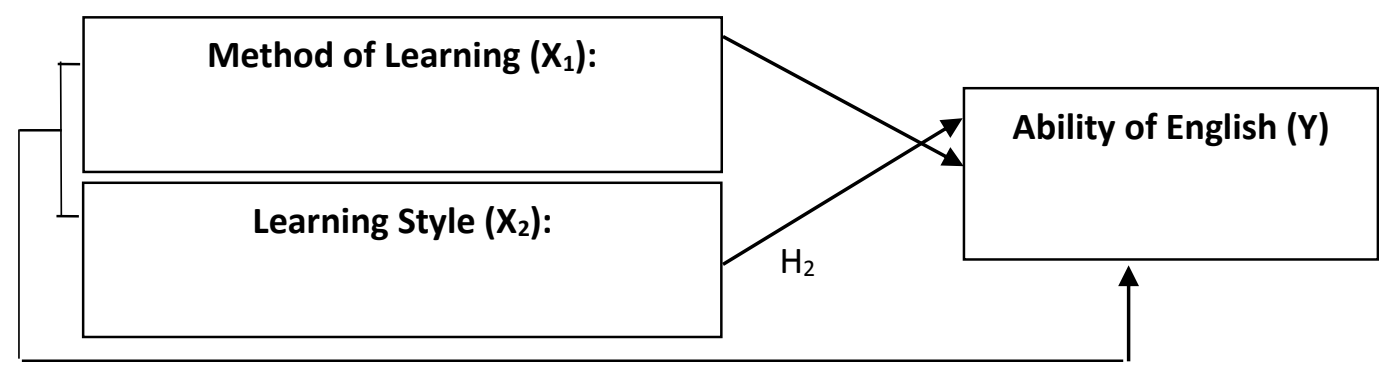

Figure 1. The Theory framework of influence and relation method of learning $\left(X_{1}\right)$ and learning style $\left(\mathrm{X}_{2}\right)$ to ability of English $(\mathrm{Y})$

\section{Hypothesis}

1. There are significant influence in the ability of a method of english english-speaking students on Akademi Pariwisata Satu Nusa.

2. There are significant influence between learning style of the ability of english-speaking students on Akademi Pariwisata Satu Nusa.

3. There are significant influence method of learning and learning style of the ability of englishspeaking students on Akademi Pariwisata Satu Nusa.

\section{METHODOLOGY}

Based on the problems and research purposes, so this study using the kind of research quantitative. And the quantitative research of this approach that variable, operational, reliabilities, hypothesis, validity and statistically meaning (Sugiono, 2012: 23-24).

The writer got the sample were 42 students. In order to understand the free variable influence on bound variables, the test and been approved who used in this research was multiple linear regression, i e as follow: $\bar{Y}=a+b_{1} X_{1}+b_{2} X_{2}+$ et

$$
\begin{aligned}
& \bar{Y}=\text { Dependent Variable (ability of English) } \\
& \mathrm{X}_{1} \quad=\text { Independen Variable (method of learning) } \\
& \mathrm{X}_{2} \quad=\text { Independen Variable (learning style) } \\
& \mathrm{a}=\text { Constant } \\
& b_{1}, b_{2}, b_{3} \quad=\text { Regression coefficient } \\
& \text { et } \quad=\text { Error term }
\end{aligned}
$$

\section{RESULT AND DISCUSSION}

In accordance with the total sample has been assigned, then on this research the writer successfully got the result of the questionnaire for 42 respondents. Then the answer to these respondents processed in descriptive statistics below, so the results can be described in table form as follows: 


\begin{tabular}{|l|l|l|l|l|l|}
\hline \multicolumn{7}{|l|}{ Table 2. Descriptive Statistics } \\
\hline & N & Minimum & Maximum & Mean & Std. Deviation \\
\hline Ability of English & 42 & 68 & 96 & 77,93 & 6,993 \\
\hline Method of Learning & 42 & 57 & 84 & 71,24 & 8,066 \\
\hline Learning Style & 42 & 72 & 96 & 82,48 & 6,783 \\
\hline Valid N (list wise) & 42 & \multicolumn{5}{c|}{ (The result of sports data, 2020) }
\end{tabular}

The table describes that the maximum and minimum reached each variable and the average and deviation standard based on responses forty-two respondents

\section{Testing the Quality of Data The Testing of Validity}

The validity of exactness or great precision is an instrument in measuring what would be measured. On this study the writer used the correlation bivariate Pearson (moment Pearson products) to test of validity. $r$ table sought in significance 0,05 by test with 2 and the number of data $(n=42)$, so obtained $r$ table of 0,297 . Next done $r$ table compared with $r$ is in count each variable. The validity items questions to all the variables known $r$ count the charges are is below $r$ table so inferred all are valid instrument.

\section{The testing of reliability}

Reliability test used to know the consistency of a measuring instrument, whether a measuring instrument used reliably and remain consistent if such measurement repeated. The use writer's reliability testing with the cronbach's alpha. Based on the data reliability testing results known the value of cronbach's alpha average above 06 so it can be concluded that all the questions on the variables can be said it is reliable.

\section{The Testing of Hhypotheses'}

\section{Multple Linier Regression Analysis}

Multiple linear regression analysis done to test the influence of two variables namely method of learning $\left(X_{1}\right)$ and learning style $\left(X_{2}\right)$ of ability of English $(Y)$ of its yield of sports data can be seen in the table below:

\begin{tabular}{|c|c|c|c|c|c|c|}
\hline \multicolumn{7}{|c|}{ Table.3. Coeffients } \\
\hline \multirow{2}{*}{\multicolumn{2}{|c|}{ Model }} & \multicolumn{2}{|c|}{$\begin{array}{l}\text { Unstandardized } \\
\text { Coefficients }\end{array}$} & \multirow{2}{*}{\begin{tabular}{|l|}
$\begin{array}{l}\text { Standardized } \\
\text { Coefficients }\end{array}$ \\
Beta
\end{tabular}} & \multirow{3}{*}{$\begin{array}{l}\mathrm{t} \\
2,450\end{array}$} & \multirow{3}{*}{\begin{tabular}{|l} 
Sig. \\
0,019
\end{tabular}} \\
\hline & & $B$ & Std. Error & & & \\
\hline \multirow[t]{3}{*}{1} & (Constant) & 30,418 & 12,418 & & & \\
\hline & Method of Learning & 0,351 & 0,128 & 0,361 & 2,731 & 0,009 \\
\hline & Learning Style & 0,347 & 0,111 & 0,413 & 3,119 & 0,000 \\
\hline \multicolumn{7}{|c|}{ a. Dependent Variable: Ability of English } \\
\hline
\end{tabular}

(The result of sports data, 2020)

The regression in above table calculated as follows:

$\bar{Y}=\mathrm{a}+\mathrm{b}_{1} \mathrm{X}_{1}+\mathrm{b}_{2} \mathrm{X}_{2}$

$\bar{Y}=30,418+0,351 X_{1}+0,347 X_{2}$

1. $a=30,418$ means if $X_{1}$ (method of learning) and $X_{2}$ (learning style) value 0 , so $Y$ (ability of 
English) its value was 30,418 .

2. The regression coefficient variable $X_{1}$ (method of learning) of 0,351 ; what if value $X_{1}$ (method of learning) increased 1 a unit of then $Y$ (ability of English) will increased by 0,351 a unit of assuming the other indefenden variable remained value.

3. The regression coefficient variable $\mathrm{X}_{2}$ (learning style) of 0,347 ; what if value $\mathrm{X}_{2}$ (learning style) increased 1 a unit of then $Y$ (ability of English) will increased by 0,347 a unit of assuming the other indefenden variable remained value.

While the correlation coefficient and determination coefficient seen in table Model Summary as follows:

\begin{tabular}{|l|l|l|l|l|}
\hline \multicolumn{5}{|l|}{ Table 4. Model Summary } \\
\hline $\begin{array}{l}\text { MMode } \\
\text { I }\end{array}$ & R & R Square & $\begin{array}{l}\text { Adjusted } \\
\text { Square }\end{array}$ & $\begin{array}{l}\text { R } \\
\text { Std. Error of the } \\
\text { Estimate }\end{array}$ \\
\hline 1 & $0,565^{\mathrm{a}}$ & 0,319 & 0,284 & 5,739 \\
\hline \multicolumn{5}{|l|}{ a. Predictors: (Constant), Method of learning, Learning style } \\
\hline
\end{tabular}

(The result of sports data, 2020)

From the output of value a correlation coefficient $(R)$ of 0,565 , so can be concluded that there are relationships in the strong between the method of learning and learning style of the ability of English speaking students on Akademi Pariwisata Satu Nusa in Bandar Lampung. And seen from determination coefficient $\left(R^{2}\right)$ value as much as 0,319 or $31,9 \%$ it can be said that the contribution percentage of independent variable influence (the method of learning and learning style) of dependent variable (the ability of English speaking) as much as $31,9 \%$ and the rest of $68,1 \%$ influenced or described by the other factor that not included in this method.

\section{The Simultaneous and Partial Regression test}

Based on output of sports data is collected $F$ count of 9,141 , by using the belief $95 \%, \partial=5 \%$ so obtained $F$ table for $n=42$ of 2,38 because $F$ count $>F$ table so Ho were rejected and Ha received or existing influence between free variable on bound variable. So based on test $F$ above can be concluded that there is the influence of method of learning and learning style together on ability of English speaking student of Akademi Pariwisata Satu Nusa of Bandar Lampung.

Testing the regression coefficient partial variable the organization culture and supervision, by using level significance 0.05 because the two sides so $2.5 \%$ and $n=42$ obtained $t$ table of $=2,023$. While t count seen of the output of sports data is 2,731 for method of learning, 3,3119 for learning style ( $t$ count $>t$ table) and based on the $t$ this concluded in partial the method of learning and learning style of significant to ability of English speaking student on Akademi Pariwisata Satu Nusa of Bandar Lampung.

\section{CONCLUSION}

Based on the research done that has been done it can be obtained conclusion as folows:

1. Based on the results of the analysis method of learning have had a positive impact significantly to ability of English speaking student on Akademi Pariwisata Satu Nusa in Bandar Lampung.

2. Based on the analysis of the learning style of positive and significant effect on ability of English speaking student on Akademi Pariwisata Satu Nusa in Bandar Lampung.

3. The method of learning as well as the learning syle of it has some positive effects and significantly correlates with the ability of English speaking student on Akademi Pariwisata Satu Nusa in Bandar Lampung. 


\section{REFERENCIES}

Alwi, Hasan. 2012. Kamus Besar Bahasa Indonesia. Edisi 4. Jakarta: Balai Pustaka.

Brown, H.D. 2001. Teaching by principles: an interactive approach to language pedagogy-2 ${ }^{\text {nd }}$ ed, New York: Longman - Pearson Education Company.

Burn, Anne, and Joyce, Hele. 1997. Focus on Speaking. Sydney: Macquarie

Departemen Pendidikan Nasional. 2005. Panduan Pengembangan Model Pembelajaran Berbasis Kompetensi. Jakarta: Direktorat PPTK dan KPT Dirjen Dikti

De Porter, Bobbi dan Mike Hernacki. 2010. Quantum Learning: Membiasakan Belajar Nyaman dan Menyenangkan. Bandung: Kaifa.

Djamarah, Syaifu Bahri. 2010. Guru dan Anak Didik Dalam Interaksi Edukatif Suatu Pendekatan Teoritis Psikologis. Jakarta: PT. Rineka Cipta.

Ghufron, M. Nur dan Rini Risnawita, S. 2013. Gaya Belajar Kajian Teoretik. Yogyakarta: Pustaka Pelajar.

Harmer Jeremy. 2007. The practice of English language teaching fourth edition. Pearson Longman Harlow.

Hermawan, Agus. 2012. Komunikasi Pemasaran. Jakarta: Erlangga.

Iskandarwassid \& H Dadang Sunendar. 2011. Strategi Pembelajaran Bahasa. Bandung: PT Remaja Rosdakarya.

Machackova, Eva. 2009. Teaching Listening. Masaryk University Brno: Brni.

Madjid, Abdul. 2012. Belajar dan Pembelajaran. Cetakan ke-1. Bandung: $\quad$ PT. Remaja Rosdakarya.

Nasution. 2009. Berbagai Pendekatan dalam Proses Belajar Mengajar. Jakarta: PT Bumi Aksara.

Nurbiana, Dhieni. 2006. Metode Pengembangan Bahasa. Jakarta: Universitas Terbuka.

Nurjamal, dkk. 2011. Terampil Berbahasa. Bandung: Alfabeta.

Priyatno, Duwi. 2010. Paham Analisa Statistik Data dengan SPSS. Yogyakarta: MediaKom

Soenardi, Djiwandono. 2011. Tes Bahasa Pegangan Bagi Pengajar Bahasa. Jakarta: PT Indeks.

Sugiono, 2012. Statistika Untuk penelitian. Alfabeta, Bandung

Suparman, U. 2010. Psycholinguistics - The theory of language acquisition. Bandung: CV. Arfino Raya.

Tampubolon. 1990. Kemampuan Membaca Teknik Membaca Efektif dan Efisien. Bandung: Angkasa.

Tarigan, Henry Guntur. 2008. Berbicara Sebagai Suatu Ketrampilan Berbahasa. Bandung: Angkasa.

Tarigan, Henry Guntur. 2009. Pengkajian Pragmatik. Bandung: Angkasa.

Thoha, Miftah. 1998. Perilaku Organisasi. Jakarta: PT Raja Grafindo Persada. 